\title{
THE LITTLE ENTENTE AND ROMANIA FROM THE PERSPECTIVE OF 1 LITHUANIAN DIPLOMACY IN THE
}

1930s

\section{Dalia Bukelevičiūtè}

Vilnius University, Faculty of History, E-mail: Dalia.Bukeleviciute@if.vu.lt

This paper has been presented at the Second International Conference on Nordic and Baltic Studies in Romania: Black Sea and Baltic Sea Regions: Confluences, influences and crosscurrents in the modern and contemporary ages hosted by the Romanian Association for Baltic and Nordic Studies, Târgoviste, May 20-22, 2011 and is prepared as part of postdoctoral fellowship research funded by European Union Structural Funds project entitled "Postdoctoral Fellowship Implementation in Lithuania".

\begin{abstract}
:
The first diplomatic contacts between Lithuanian and Romanian representatives started in the aftermath of World War I when Lithuania was looking for the protection of her inhabitants who were still refugees in Russia. As Russia became entrenched with Bolshevism and Civil War, the Lithuanian citizens were evacuated through Romanian territory from South Ukraine and Crimea. Lithuania and Czechoslovakia established diplomatic relations in December 1919 and eventually an attempt was made to set up ties also with Romania. As a member of the Little Entente and an ally of Poland, Romania attracted the attention of the Lithuanian government. Romania recognized Lithuania de jure on August 21, 1924 and Dovas Zaunius was appointed as the first Lithuanian envoy to Bucharest. Nevertheless, during the next decade no political or diplomatic contacts between Lithuania and Romania were recorded. With the growing influence of Germany, the Soviet Union and the Little Entente on the international arena, Edvardas Turauskas was appointed on August 27, 1935 as envoy to Romania residing in Prague and later in the year Romania accredited Constantin Vallimarescu for the position of envoy to Lithuania residing in Riga. The dialogue between the two parties remained, however, occasional. When on July 21, 1940 Lithuania was occupied by Soviet Union, Turauskas visited the Romanian Legation in Bern and presented a note of protest in this respect. Romania did not acknowledge Lithuanian occupation and annexation.
\end{abstract}




\section{Rezumat:}

Primele contacte între reprezentanții români şi lituanieni au început după primul război mondial, atunci când Lituania căuta să asigure protecția locuitorilor săi, care erau încă refugiați în Rusia. Cum în Rusia a preluat puterea bolşevismul, cetătenii lituanieni au fost evacuați pe teritoriul românesc din Ucraina de Sud şi Crimeea. Lituania şi Cehoslovacia au stabilit relații diplomatice in decembrie 1919 şi în cele din urmă s-a făcut o încercare de a crea, de asemenea, legături cu România. Ca membru al Micii Înțelegeri şi aliat al Poloniei, România a captat atenția guvernului lituanian. România a recunoscut de jure Lituania la 21 august 1924 şi Dovas Zaunius a fost desemnat ca primul reprezentant lituanian la Bucureşti. Cu toate acestea, în cursul următorului deceniu nu au existat contacte politice sau diplomatice între Lituania şi România. Odată cu creșterea influenței Germaniei, a Uniunii Sovietice şi a Micii Înțelegeri pe arena internațională, Edvardas Turauskas a fost numit, la 27 august 1935, ministru în România cu reşedința la Praga şi, mai târziu, în cursul aceluiaşi an, România l-a acreditat pe Constantin Vallimarescu în poziția de ministru în Lituania cu reşedința în Riga. Dialogul între cele două părți a rămas, totuşi, ocazional. Atunci când la 21 iulie 1940 Lituania a fost ocupată de Uniunea Sovietică, Turauskas a vizitat Legația Română din Berna şi a prezentat o notă de protest în acest sens. România nu a recunoscut ocuparea şi anexarea Lituaniei.

Keywords: Romania; Lithuania; Prague; diplomatic relations; 1930s; Little Entente; Baltic Entente

The growing intensity of political relations in Europe in the 1930s brought up the idea of collective security. The small and medium countries faced the inevitable necessity to seek for ways out of the international tension created by Germany, Poland, the USSR, Italy and the Great Powers. The Little Entente, which came into being as a bloc of countries as far back as 1920, was able to provide at least some measure of security to Romania. The situation of Lithuania was quite the opposite - it was not a party to any political alliances and it had serious political territorial disputes with the neighbouring Poland, as well as problems with Germany as regards the German minority. The small countries began to realise that they could only maintain political stability and play an active and influential role in foreign policy (in particular, in the League of Nations) in cooperation with other countries.

At the dawn of the 1930s, foreign policy did not promise any remarkable turning-points. The foreign policy of Lithuania went through a peculiar period at that time, which also manifesting in the lack of attention towards the countries of Central Europe and the Balkans. Several attempts to establish diplomatic relations with Romania and Yugoslavia resulted in a failure. Prague was not considered an important political centre, therefore, only a charge d'affaires of Lithuania, Jurgis Brèdikis, resided in the city. In 
spite of that, the Foreign Ministry of Lithuania saw Prague as the most important diplomatic post in the area. The Lithuanian diplomat was required to provide information on the Little Entente and to monitor the policies of Romania and Yugoslavia. In spring 1932, following the conference of the Little Entente in Belgrade, Jurgis Breddikis noted that "the countries of the Little Entente do not miss the opportunity to express their political and military significance on the key European issues and to highlight their obvious political independence."1 In 1932, the newly appointed envoy extraordinary and minister plenipotentiary of Lithuania to Czechoslovakia Jonas Aukštuolis was able to report more detailed information to Kaunas on the events in the Little Entente.

The year 1933 witnessed a growing interest of Lithuania in the Little Entente following the signing by Czechoslovakia, Romania and Yugoslavia of the Pact of Organisation in February. The document strengthened the trilateral cooperation and the alliance's role in the European foreign policy. The three countries also undertook not to sign unilateral treaties with third countries without the preliminary consent of all Little Entente members. Italy, Germany, the USSR, and Poland were considered the key third countries at that time. Lithuania was most interested in the relations between the members of the Little Entente and the aforementioned powers. Following the signing of the Pact on Organisation, Jonas Aukštuolis drew the attention of the Ministry of Foreign Affairs of Lithuania to the fact that the relations between the Little Entente and Poland became particularly important and the position of the Little Entente in respect of Poland could play a role in the future relations between Poland and Germany. ${ }^{2}$

The position of Hungary in Europe was not of significant importance to the policy of Lithuania; hence, attention was not paid to the relations between the Little Entente and Hungary. Lithuania followed the events and recorded the facts communicated by its diplomats, but it failed to express any reaction, being content to remain a passive observer. It was far more interested in the circumstances of consolidation of the Little Entente and the attempts of the regional alliance to remain outside the sphere of interest of the Great Powers. The Pact of Organisation also covered the circumstances of economic cooperation; however, Jonas Aukštuolis was rather sceptical about Czechoslovakia's interest in developing the economic relations with Romania and Yugoslavia by

\footnotetext{
${ }^{1}$ Lithuania's charge d'Affaires in Czechoslovakia J.Brèdikis report of 25.05.1932 from Prague to the Ministry of Foreign Affaires of Lithuania, Lithuanian Central State Archive (hereafter, LCVA). F.383.Ap.7.B.1310.L.11-13.

2 Lithuania's envoy in Czechoslovakia J.Aukštuolis report of 25.02.1933 from Prague to Foreign Ministry of Lithuania, LCVA. F.383. Ap.7. B.1451. L.1.
} 
asserting that due to their similar economic structure, Yugoslavia and Romania were more likely to cooperate between themselves than with Czechoslovakia. According to him, the strength of the Little Entente could be seen in contemporary political rather than economic ties. Economic ties were a matter of future and were dependent on policy, and not solely on the political development within the Little Entente." 3

In the meantime, strange though it may seem, situations were recorded when foreign diplomats gathered in Kaunas to discuss international relations developments according to information provided by the Ministry of Foreign Affairs of Romania. The envoys of Czechoslovakia and Italy M. Niederle and G. Amarodi discussed in Kaunas the potential Polish corridor to be created at the expense of Lithuania and the Lithuanian-Polish relations. G. Amarodi shared documents received from Budapest (from the Legation of Italy) and the minister of foreign affairs of Romania was informed that in order to have the USSR-Polish agreement signed, a secret treaty on the division of the spheres of influence in the Baltic countries was discussed, which would place Lithuania into the sphere of influence of Poland, while Latvia and Estonia were to be attributed to the USSR. ${ }^{4}$

The international cooperation essentially changed in 1934 after the creation of the Baltic Entente and the signing of the Balkan Pact, i.e. the cooperation acquired a completely different form. The Balkan Pact between Romania, Greece, Yugoslavia and Turkey was concluded in February, whereas Lithuania, Latvia and Estonia founded the Baltic Entente in September. The main connection between these alliances was their desire to preserve the stability and peace in the region, but their members lacked confidence in one another and the capacity of negotiating with countries that were not members to their respective alliance. According to the minister of foreign affairs of Lithuania Stasys Lozoraitis, the Baltic Entente acceded to other regional treaties, i.e. the Little Entente and the Balkan Pact, and sought the same goals. ${ }^{5}$

The Lithuanian politicians' interest in the Little Entente mainly focused on Czechoslovakia, which was considered the most influential member of the Little Entente. Romania and Yugoslavia received far less

\footnotetext{
${ }^{3}$ J.Aukštuolis report of 11.03.1933 from Prague to Foreign Ministry of Lithuania, LCVA. F.383. Ap.7. B.1451.L.72.

4 Czechoslovakia's charge d'Affaires in Lithuania M.Niederle report of 01.03.1933 from

Kaunas to the Ministry of Foreign Affaires of Czechoslovakia, Archive of Ministry of

Foreign Affaires of Czech Republic (hereafter, AMZV), Pz-Kaunas. č.j.35/duv.

5 Czechoslovakia's envoy to Lithuania J. Skalický's report of 14.12.1934 from Kaunas to the

Ministry of Foreign Affaires of Czechoslovakia, AMZV.Pz-Kaunas. č.j.330-duv.
} 
attention. One of the Lithuanian diplomats once noted that they should not be interested in the issues that were not related to Lithuania. Lithuania was little interested in the relations between the members within the Little Entente; it was far more interested in the political power of the Little Entente and its regional and European foreign policy.

Thus, Romania, as a member of the Little Entente, was mainly of interest to the Lithuanian politicians for its relations with Poland and the USSR. Edvardas Turauskas discussed the two issues in the first meeting with the minister of foreign affairs Nicolae Titulescu in Bucharest. Titulescu professed to possess a document at his disposal whereby Russia recognised Bessarabia's belonging to Romania and emphasized that his country encountered no problems with the USSR. Turauskas was however reluctant to believe in Titulescu's assertions. The Lithuanian envoy was also interested in the reasons of the dwindling relations between Romania and Poland. Titulescu asserted that Poland was too keen on influencing Romanian foreign policy, which he found unacceptable. He acknowledged that the Poles were not satisfied with his personality either. ${ }^{6}$ On the other hand, as a member of the Little Entente, Romania perfectly understood its political weight. Titulescu professed to Turauskas his belief that: "you are in favour of the Little Entente and the policy of Romania in general". ${ }^{7}$

Starting with 1935 Turauskas was the envoy to all three members of the Little Entente, but he used to receive most information on the conferences of the Little Entente and their resolutions from Czechoslovakian politicians, as he maintained his residence in Prague. In 1936 he was very active in trying to find out the circumstances of the nonaggression draft treaty drawn up between Romania and the USSR and approached various politicians in this regard. In April, Kamil Krofta, the minister of foreign affairs of Czechoslovakia, reassured him that such a treaty was to be concluded before long. ${ }^{8}$ The issue was again addressed in November, when the King of Romanians paid a visit to Prague. Krofta reassured Turauskas that Romania was on the side of Czechoslovakia regarding the development of relations with the USSR because "Romania will also be able to take advantage of such good relations and it will not face any threats from the side of the USSR." Turauskas was prone to evaluate the opinions of the Romanian envoy Theodor Emandi and learned

\footnotetext{
${ }^{6}$ Lithuania's envoy in Romania (Czechoslovakia and Yugoslavia too) E. Turauskas' report of 22.11.1935 from Prague to the Ministry of Foreign Affaires of Lithuania, LCVA. F.648. Ap.1.

B.14. L.320-323.

7 Ibid., L.320-323.

8 E. Turauskas report of 17.06.1936 from Prague to Foreign Ministry of Lithuania,

LCVA.F.648.Ap.1.B.15.L.87.
} 
that Krofta looked very optimistic during the king's visit (especially as regards the relations with the USSR). ${ }^{9}$ In May 1937 Victor Cadere, the envoy of Romania in Prague, tried to explain to the Lithuanian diplomat the reasons why the treaty with the USSR was not concluded: Titulescu was willing to enter into the treaty with the USSR and would have concluded it, if not for Litvinov's persistence to leave the question of Bessarabia open. That also triggered the changes in the Balkans. Cadere explained that the Romanian society did not support the negotiations with the USSR led by Titulescu. If such a treaty was concluded, Yugoslavia would recognise the USSR de jure, and the Little Entente would enter into the reciprocal treaty with the guarantee from France. ${ }^{10}$ In the meantime, foreign minister Victor Antonescu was not willing to disclose the circumstances of the treaty to Turauskas, limiting himself to the remark that the relations between Romania and the USSR were good.11

The changes in Romania's foreign policy in respect of Poland in 1936-1937 were not only of interest to Lithuanian politicians but also to the USSR diplomats residing in Kaunas. In 1936 the relations between Poland and the members of the Little Entente Czechoslovakia and Romania were actively monitored by the envoy of the USSR in Kaunas Michail Karski, who evaluated the visit of Antonescu by expressing his suspicions as to whether France did stand behind this cooperation. He also expressed his reasonable doubts that the excessive involvement of Poland in international policy could diminish the role of the French-USSR treaty. ${ }^{12}$ The new USSR envoy to Lithuania B.N. Podolski was haunted by similar moods and did not conceal that Moscow paid considerable attention to Antonescu's visit in Warsaw. Podolski confessed to J. Skalicki that the visit of Antonescu to Warsaw was a change in the foreign policy of Romania which ran against the development of Romanian-USSR relations, as well as against the interests of the Little Entente. The Soviet diplomat was surprised to see the increased weight of Poland in Romania; he went on to assert that changes, which could divide the Little Entente, were underway. However, the Czechoslovakian diplomat did not believe that the visit should be

\footnotetext{
${ }^{9}$ E. Turauskas report of 09.11.1936 from Prague to Foreign Ministry of Lithuania, LCVA.F.648.Ap.1.B.15.L.119-120.

${ }^{10}$ E. Turauskas report of 04.05.1937 from Prague to Foreign Ministry of Lithuania, LCVA.F.648.Ap.1.B.16.L.55.

11 E. Turauskas report of 18.05.1937 from Prague to Foreign Ministry of Lithuania, LCVA.F.648.Ap.1.B.16.L.63-64.

12 J. Skalický secret report of 20.12.1936 from Kaunas to Foreign Ministry of Czechoslovakia, AMZV.Pz-Kaunas. C.j.366-duv.
} 
evaluated by anything but dark shades; Prague was notified of Antonescu's visit and no serious outcomes were expected out of it. ${ }^{13}$

The evolution of the Polish-Romanian relations was also discussed during Turauskas' visit to Bucharest in May 1937. Antonescu was reluctant to go into details, he only confirmed that "we agree on all the issues as far as both countries are concerned." In the assessment of the changes in Romania's foreign policy, he said that there were no essential changes and that they only revived their union with Poland, which was deteriorating due to personal disagreements between Titulescu and Beck. The Lithuanian diplomat was interested whether the alliance with Poland was only concerned with certain borders or the overall borders of both countries were envisaged. Antonescu replied that the alliance was not targeting against any country and guaranteed the recognition of borders of the two countries. Nevertheless, Turauskas noted in his report to the Ministry of Foreign Affairs of Lithuania that Antonescu was right in de jure terms, whereas in practice the alliance was concerned with the eastern borders exclusively. ${ }^{14}$

According to the Czech historian Z. Sladek, we could no longer speak about the unity of the Little Entente by 1936, whereas the signing of the Austrian-German treaty on 11 June marked the end point in the collective security policy, and the countries of Central Europe fell under Germany's sphere of influence. ${ }^{15}$ It should be noted that the Lithuanian diplomats were gradually getting signals of the dwindling unity within the Little Entente. The Czechoslovakian politicians did never openly express that to Turauskas, and the actual situation was concealed under a veil of optimism. In 1937 Turauskas pursued an active diplomacy in Prague in order to find out what were the interests of the Little Entente in signing the non-aggression treaty with Hungary. In February 1937, Krofta did not any longer conceal that the idea would remain unfulfilled because the Romanians hesitated and Yugoslavia demonstrated its opposition. Therefore, the Czechs could not force them to enter into such an agreement. ${ }^{16}$ In summer, not even the President of Czechoslovakia Edvard Beneš concealed from Turauskas that essential differences between the position of Czechoslovakia and the ones of Romania and Yugoslavia were

\footnotetext{
13 J. Skalický report of 05.02.1937 from Kaunas to Foreign Ministry of Czechoslovakia, AMZV.Pz-Kaunas. C.j.43-duv.

14 E. Turauskas report of 18.05.1937 from Prague to Foreign Ministry of Lithuania,

LCVA.F.648.Ap.1.B.16.L.63-64.

15 Sládek Zd. Mála dohoda. Praha, 2000.s.195, 197.

${ }^{16}$ E. Turauskas report of 02.02.1937 from Prague to Foreign Ministry of Lithuania,

LCVA.F.648.Ap.1.B.16.L.7-8.
} 
apparent in the Little Entente. ${ }^{17}$ Of course, Yugoslavia and its attempted withdrawal from the Little Entente and that time became the focus of attention.

The treaty signed between Yugoslavia and Italy in March essentially changed the substance of the Little Entente. Therefore, in June the Ministry of Foreign Affairs of Lithuania was struck by the news of Italy's endeavour to disband the Little Entente, and the treaty between Italy and Yugoslavia meant that one of the members of the Little Entente was already "pull out" of it. ${ }^{18}$ Even though the Little Entente was formed against Hungary, the conclusion on the ineffectiveness of the Little Entente included a remark that "the Little Entente is already ineffective even against Hungary". According to the Lithuanian diplomat, Italy may seek to sign the agreement with Romania, case in which the Little Entente would remain "just a memory", but at the same time he expressed his doubts as to its probability because Romania highly depended on the influence of France and Czechoslovakia. ${ }^{19}$

Lithuanian diplomats were also interested in the negotiations between the Little Entente and Hungary over the situation of Hungarian minorities in the countries of the Little Entente. Romania expressed a rather categorical position on this issue and therefore the Ministry of Foreign Affairs of Lithuania was informed that Romania had changed its positions and refused to make a statement on the Hungarian national minority, reminding that the Little Entente was created against revisionism and it would be to abandon its major goal if reconciliation with Hungary was achieved (even though other members of the Little Entente supported such a statement). ${ }^{20}$ Czechoslovakia was dissatisfied with Romania's behaviour; its minister of foreign affairs even complained to Lithuania's minister of foreign affairs Stasys Lozoraitis in Geneva in October that Antonescu hesitated to take any step on the issue of Hungarian national minorities. ${ }^{21}$

In 1938 the issue of the German national minority and German interests with regard to Czechoslovakia gave the final blow to the Little Entente. However, in 1937 the minister of foreign affairs of Czechoslovakia explained to the Lithuanian diplomat that Romanians were well aware that

\footnotetext{
${ }^{17}$ E. Turauskas report of 03.06.1937 from Prague to Foreign Ministry of Lithuania, LCVA.F.648.Ap.1.B.16.L.78-81.

18 E. Turauskas report of 12.06 .1937 from Prague to Foreign Ministry of Lithuania, LCVA.F.648.Ap.1.B.16.L.90-91.

19 Ibid., L.90-91.

20 Ibid., L.107.

${ }^{21}$ Memo of Foreign Minister of Lithuania S. Lozoraitis of 26.10.1937,

LCVA.F.648.Ap.1.B.53.L.110.
} 
if Germany attacked Czechoslovakia, Romania's destiny would be similar or even worse because the Russians would also invade Romania. Therefore, according to the Czechoslovakian chief of diplomacy, Romania, although only partially, did support Czechoslovakia22 in spring 1938. Nevertheless, right before the Sinaia conference, he already acknowledged that the Little Entente was faring through a crisis and the conference was not expected to bring any positive outcomes. Czechoslovakia did not expect any support from Yugoslavia, "but Romania currently expresses more concern and understanding of Czechoslovakia's situation. Romania acquires a deeper understanding of the importance of its relations with the USSR." 23

The news with regard to the Little Entente reaching Lithuania from Prague testified that on the verge of war the countries of the Little Entente were most likely to act not as a united body, as they had already failed to react to arising threats as a solid political bloc for a number of times before. The Lithuanian politicians, immersed in solving their political issues with Poland and Germany, as well as the integrity of the Baltic Entente, remained only passive observers of the break-down of the Little Entente. They realised the importance of the treaties ensuring peace in Europe, therefore, they paid considerable attention to the relations between Romania and the USSR; the territorial conflicting interests were not of the least importance. The case of Lithuania shows that the actions of the USSR diplomacy extended to small countries as well. It should be noted that Poland was still considered the enemy of Lithuania in the 1930s; hence, the concern of the Lithuanian politicians about the improved relations between Romania and Poland in 1936-1937 was not gratuitous.

\section{References:}

\section{Archives:}

A. Lithuanian Central State Archive, folders:

- F. 383. Ap. 3. B. 293.

- F. 383. Ap. 7. B. 2035.

- F. 648. Ap. 1. B. 14.

- F. 648. Ap. 1. B. 16.

- F. 648. B. 22.

- F. 648. B. 30 .

- F. 648. B. 40.

\footnotetext{
22 E. Turauskas report of 12.06.1937 from Prague to Foreign Ministry of Lithuania, LCVA.F.648.Ap.1.B.16.L.87.

${ }^{23}$ E. Turauskas report of 29.04.1938 from Prague to Foreign Ministry of Lithuania, LCVA.F.648.Ap.1.B.16.L.163-164.
} 
The Little Entente and Romania from the perspective of Lithuanian diplomacy in the 1930s

- F. 648, Ap. 1. B. 53.

- F. 648. Ap. 1. B. 55.

B. Archive of Ministry of Foreign Affaires of Czech Republic, folders:

- Pz-Kaunas 1937, č.j. 87-duv.

- Pz-Kaunas 1937, č.j. 43-duv. 